\title{
As entrevistas de Hilda Hilst
}

Luisa Destri

Fico besta quando me entendem: entrevistas com Hilda Hilst. Organização de Cristiano Diniz. São Paulo: Globo, 2013.

Ao apresentar a seleção de entrevistas concedidas por Hilda Hilst entre 1952 e 2003, o organizador do volume, Cristiano Diniz, vai diretamente ao que mais interessa: retomando os gêneros praticados pela autora - poesia, ficção, teatro e crônica -, afirma que ela "soube escrever" também no gênero entrevista; com "maestria", teria ajudado a criar e divulgar "uma imagem que deixou marcas, que ainda ecoam quando seu nome é lembrado". Seus traços principais, "dona de uma inteligência incomum, sem papas na língua, ousada, desconcertante, provocativa e... 'louca"'.

Os textos reunidos em Fico besta quando me entendem priorizam o momento de criação dessa imagem. Trata-se, segundo o organizador, da década de 1990, quando a autora inicia a publicação de obras obscenas e a redação de crônicas para o jornal Correio Popular, de Campinas. A exposição pública mais intensa, e voluntária, dá origem então a um "boom de entrevistas", na coletânea representado por sete das 21 matérias reunidas. Nesses textos se pode flagrar, argumenta Diniz, como se constituiu a imagem excêntrica da autora, cuja cristalização seria, no limite, responsável pela "tremenda indiferença”" (não só da imprensa) ao projeto literário de Hilst. Ali estariam, de um lado, a autora, "irritada, irônica e propositalmente distraída", demonstrando "quase nenhuma disposição para conversar sobre seu trabalho"; de outro, interlocutores que "ajudaram a fortalecer o retrato de uma obra literária de difícil leitura e entendimento". Para Diniz, a evasão da entrevistada e a falta de empenho dos jornalistas (ou as limitações impostas pelos próprios veículos) constituem respectivamente a "armadilha" e o "corte" que produziram a "cicatriz" do desinteresse pela obra de Hilda Hilst.

A incisão se faz visível a partir de títulos de entrevistas presentes na própria coletânea: em 1986, "Hilda Hilst, uma emocionada conversa sobre a vida, o amor e o ato de escrever"; em 1991, "Palavras abaixo da cintura"; "O sofrido caminho da criação artística, segundo Hilda Hilst", de 1975; e "A obscena senhora Hilst”, de 1994. Já o desinteresse é insistentemente referido pela própria autora, a exemplo da afirmação que faz à revista Interview em 1991: "Eu era uma espécie de KGB literária, que ninguém lia, e agora $[\ldots]$ passei a ser uma maldita de todos os tempos". 
Entre a espécie de canonização promovida pela imprensa e a publicitação da suposta entrega de Hilst à banalidade, há discretos elementos que a própria coletânea veicula. Quando se crê diante de um público interessado em sua obra, e não de um veículo de divulgação mais ampla de seu trabalho, ela francamente delimita o território de suas crenças pessoais, o plano objetivo que problematiza em sua literatura e a superfície por onde transitam os atores do mercado. Quer dizer: a mulher que equipara sua literatura aos serviços secretos da unss está algo distante daquela que em entrevista concedida ao amigo Caio Fernando Abreu questiona o papel da literatura num país formado por " 30 milhões de analfabetos, [e] mais ou menos 70 milhões de pessoas com uma vida miserável". Por isso, para considerar a construção da imagem operada por Hilst e a necessidade de reivindicar um lugar mais alto para a sua literatura, convém olhar para além de duas metades.

Nesse sentido, a entrevista que abre a coletânea forma, com a última, um notável espelho. Temas, questões e referências coincidentes permitem observar a evolução desse discurso no contato com os interlocutores. "Palestra com Hilda Hilst", publicada por Alcântara Silveira no Jornal de Letras do Rio de Janeiro no ano seguinte ao lançamento do segundo livro de poemas da autora, Balada de Alzira (1951), é resultado de um "encontro casual" no bar do Museu de Arte Moderna de São Paulo. Estudante de Direito no Largo São Francisco, a "jovem poetisa” procura expressar com irreverência preocupações que lhe serão constantes. A exemplo do que ocorre em seus primeiros versos, porém, parece ainda não superar a ingenuidade ou a estereotipia. Critica a existência de igrejinhas ("Meu amigo, desconheço as atividades do Clube de Poesia, de que fui expulsa"), afirma-se como ser de exceção ("Meus poemas nascem porque precisam nascer"), cobra seriedade da crítica literária ("há principalmente o elogio fácil") e reivindica que uma autora "forte e potente" como Cecília Meireles seja chamada poeta, e não poetisa. Já Silveira tenta construir a imagem de uma mulher segura e em amadurecimento. Se a poeta "conseguiu se manter imune à literatura do Largo São Francisco", trazendo, no segundo livro, poemas "mais graves e menos femininos", a personagem masculamente inspira respeito e desejo: "A poetisa tomou um gole de uísque. Tomamos nossa água tônica e voltamos a assediá-la, agora a propósito...”, afirma o narrador do encontro.

A entrevista realizada 51 anos depois por Leila Gouvêa para o D.O. Leitura retrata uma escritora que "usufrui a reconhecida condição de ser um dos maiores poetas vivos do Brasil”. Em 2003, já então traduzida, editada, premiada e estudada, Hilst afirma: "[...] eu era uma tábua etrusca, totalmente incompreensível. [...] não sei o que 
aconteceu mas as pessoas começaram a entender". Ainda assim, diz que ser poeta no Brasil "é uma merda". Também Cecília Meireles retorna à conversa, dessa vez mencionada pela jornalista, que indaga sobre a possível influência na obra da entrevistada. Hilda nega se tratar de uma "presença fecundante", e completa: "Não chegamos a nos tornar amigas. Ela era muito delicada e evidentemente uma pessoa sensível". A feminilidade é agora valorada positivamente, pois introduz o relato de uma carta enviada pela poeta de Viagem em apoio e estímulo à iniciante autora de Balada de Alzira.

Entre outras coincidências com a matéria de Alcântara Silveira, há ainda a referência a Carlos Drummond de Andrade - no primeiro caso, por iniciativa da entrevistada, que em 1952 afirma se tratar do "homem mais inteligente do Brasil"; no segundo, mencionado pela entrevistadora, e motivando a transcrição de um poema composto pelo mineiro em homenagem a Hilst ("Hilda, estrela Aldebarâ"). Quanto às panelinhas e instituições literárias, assim responde à jornalista interessada em saber se teria alguma vez considerado integrar a Academia Brasileira de Letras: "Nunca. E nem me sinto atraída, apesar da Academia ter muita gente interessante. O que eu realmente desejo é ganhar o Nobel".

Chama a atenção, em primeiro lugar, a postura de Hilda Hilst com relação a seus pares. Jovem, buscava colocar-se em igualdade com Drummond e Cecília, inclusive aproveitando para se distanciar de uma imagem negativamente feminil. Madura, sente-se à vontade para demonstrar admiração. Mais segura é também a maneira de expressar a opinião sobre o próprio ofício. Se para tal citava, em 1952, versos do livro então lançado ("estão terrivelmente sozinhos/ os doidos, os tristes, os poetas"), em 2003 é concisa e despachada, limitando-se a dizer que "ser poeta é difícil em qualquer lugar". Ainda nesse sentido, o prazer de se dizer persona non grata no Clube de Poesia dá lugar ao respeito por integrantes da $\mathrm{ABL}$ e à confissão de que anseia por recompensa.

O cotejo entre as duas entrevistas é eloquente também em termos da radical individualidade que Hilda Hilst procurou afirmar. Pois, ainda que Diniz afirme ter-se guiado pelo objetivo de oferecer uma imagem ampla da escritora, em que se incluíssem sua experiência pessoal e a opinião sobre a literatura e a cena literária, as colocações da entrevistada, mesmo ao longo de cinco décadas, tornam a tarefa quase impossível: é sua personalidade, e não a opinião sobre questões diversas, que quase sempre emerge do conjunto de suas declarações.

Uma relevante exceção talvez esclareça o sentido da regra. Trata-se da transcrição de uma conversa entre Hilst e os participantes do curso "Feminino singular", promovido pelo Arquivo Público e Histórico do Município de Rio Claro (sP) em 1987. Sua 
primeira fala aponta o "engodo" em que consiste o escritor apresentar-se em público, pois apenas ao escrever mostraria sua "cara" verdadeira. E pergunta, então, qual "cara" deve assumir. Todos concordam que a conversa será "informal e verdadeira", e mais de uma vez a autora demonstra seguir a proposta à risca.

Comparem-se, por exemplo, o episódio que narra e a explicação que para ele oferece. Trata-se de uma palestra ocorrida no âmbito do Programa do Artista Residente, da Unicamp, de que participou na década de 1980:

Me lembro que, certa vez, uma moça começou a bocejar e perguntei: "Será que você não tem amebas? Porque ameba é uma coisa que deixa a pessoa muito cansada". Depois disso me chamaram a atenção: eu estava ofendendo as pessoas. [...]. Eu ficava muito irritada porque não sentia vigor, fervor nas pessoas. Não levantavam nenhum problema. Foi uma experiência que me deixou meio triste. Não havia nada a discutir. Tem-se uma ideia das universidades, mas é uma ideia meio utópica, porque, na verdade, não há muito, ou melhor, não há nada a discutir nelas.

Para além de explicitar a visão pessoal de um episódio típico de seu anedotário, inserindo-o em uma discussão institucional mais ampla, Hilda Hilst efetua, nesse encontro, interrupções importantes em seu raciocínio, que corroboram a hipótese de sua sinceridade. Os famosos ataques aos editores, de que é exemplo o dirigido ao mais fiel deles - "adora ter os livros em casa. Ele não vende, ele põe tudo no quarto dele e fica namorando os livros"1 -, aqui dão lugar a um comentário apenas elogioso sobre o mesmo Massao Ohno (“é um editor que gosta de fazer livros lindíssimos") e à indicação de um pensamento mais consistente sobre o mercado editorial, que considera também o público leitor brasileiro ("Eu não penso nunca no leitor, quando estou escrevendo. Se eu pensasse, seria ótimo porque estaria sendo vendida. Meu editor fica sempre chateadíssimo e diz: 'Hilda, você não vende nada. É uma coisa horrorosa'”).

Ao ser levada a falar sobre o que considera ser a "essência do homem", quando platonicamente confessa entender "toda a nossa vida" como a busca de uma bondade

1. O trecho é da entrevista, não presente na coletânea, concedida por Hilda Hilst ao programa Certas Palavras, da Rádio CBN, em 25 de maio de 1990, por conta do lançamento de O Caderno Rosa de Lori Lamby. Tive acesso à gravação no Centro de Documentação Alexandre Eulalio, na Unicamp, onde está depositado o acervo da autora. 
e perfeição conhecidas em "outra vida", trata de fugir ao assunto: "acho que o tom está se tornando muito sério. Eu preferia que fosse mais leve, porque ninguém vai ficar meu amigo, assim". A postura é semelhante no momento em que um ouvinte lhe pergunta sobre as experiências paranormais que havia realizado durante a década de 1970. Embora não se negue a manter-se no assunto, inicialmente pondera: "Falei muito sobre isso e depois me chamaram de bruxa, feiticeira e tudo o mais. Resolvi, então, ficar em silêncio". Verdadeira e informal, problematiza os assuntos à medida do que supõe ser o perfil do público.

O tom é bastante diverso do que adota em uma entrevista publicada no jornal O Estado de S. Paulo em 1975. Após a própria escritora conduzir a conversa para seus experimentos paranormais, o jornalista, embora manifestando respeito pelas opiniões expressas, pede para passarem a outro tópico. "Sobre a problemática mística", afirma, "penso que o assunto não caberia nesta entrevista." A entrevistada sutilmente critica a tentativa de tornar a conversa mais leve: "Difícil responder a todas as perguntas. Você pede vida, morte, milagres, mas grande parte do que deseja saber está dentro dos meus textos". Refere "homens de ciência" que conduzem experimentos semelhantes, capazes de "mudar o conceito que têm da morte", e queixa-se da "falta de informação" sobre o assunto. Contrapõe, assim, a seriedade de suas crenças e iniciativas ao "rótulo de absolutamente delirante" que lhe imprimira o público e, possivelmente, ao que julgava ser a opinião do entrevistador.

Esse diálogo é um exemplo do sutil embate em que a escritora transformou algumas entrevistas. Entre 1970 e 1980, os jornalistas com frequência direcionavam a conversa para a mudança de Hilda Hilst para a Casa do Sol, ocorrida em 1966. Notabilizada como a jovem socialite que deixou a vida agitada na capital paulista para, em Campinas, isoladamente dedicar-se à literatura, a poeta muitas vezes emerge como uma sacerdotisa da literatura: professando a fé na criação literária, recolheu-se a um mosteiro profano, onde poderia austeramente cultivar sua vocação. Ocorre também de valer-se do diálogo com a imprensa para exercer um proselitismo leigo: "Como vamos poder, numa página de jornal, definir toda uma conduta literária que, a meu ver, não pode deixar de ser também entranhadamente ética?”, pergunta ao entrevistador, Léo Gilson Ribeiro, que lhe pedira para comentar o hermetismo de sua literatura. E afinal confessa o maior objetivo de seu trabalho: "proporcionar ao outro [...] uma visão definitiva de si mesmo, com suas potencialidades, falhas e virtudes".

A década de 1980, a segunda mais bem representada na antologia, é, assim, decisiva para considerar o domínio de Hilda Hilst sobre sua imagem. Embora o organiza- 
dor considere estar aí a demonstração de que em certo momento houve interesse "pelo projeto literário e pelas ideias de Hilda", é demais evidente o empenho da autora em conquistar algum público. Impressiona o quanto se mostra resoluta em jamais ceder às facilidades de um mercado que se serve também da disposição para entrevistas a fim de baratear o produto.

Isso não quer dizer que a partir de certo momento Hilda Hilst tenha decidido ceder. Pelo contrário, aliás. Com o conhecimento mais amplo do início e do fim da carreira é possível compor o retrato de uma trajetória nada acidental. Com a sutileza de quem segue um projeto consequente, a autora de A obscena senhora $D$ constrói um discurso que, partindo da radical consciência do ofício, empenha-se na composição da imagem pública, na constituição de estratégias para inserir a alta literatura em um mercado que parece rejeitá-la e na criação de um espaço próprio na literatura brasileira para sua obra.

Entrevistas concedidas a outras mídias podem iluminar mais facilmente o teor de seu discurso durante os anos 1990 - sobretudo no que diz respeito à habilidade em encarnar personagens. O melhor exemplo talvez esteja em uma gravação da TV Cultura de 1990, hoje disponível na internet com cenas em off, ${ }^{2}$ gravadas para que a jornalista refizesse as perguntas, corrigindo um problema técnico sem que a escritora precisasse responder novamente. Ali se assiste a um jogo: em off, a autora de O Caderno Rosa de Lori Lamby oferece respostas diferentes das que tinha dado ao se dirigir ao público; essas divergências iluminam as gargalhadas que, durante a gravação oficial, Hilda quase não conseguira conter.

Vistas assim nesse contexto, as "respostas prontas" podem então representar indícios de uma Hilst estrategista. Tendo compreendido o que o mercado lhe poderia dar, tratou de cultivá-lo, ainda que muitas vezes esse cultivo implicasse vitimar-se ou insistir em queixas. Nesse caso, aliás, a obra curiosamente ilumina a biografia, porque em seus livros jamais um ser de exceção como o escritor encontra consolo "nas gentes".

Pois acima de tudo Fico besta quando me entendem testemunha, com sua própria existência, que Hilda Hilst não foi preterida. Bem diversamente, aliás: para além do constante interesse da imprensa, teve a edição de suas obras completas contratada quando ainda vivia, e em condições atípicas, reservadas aos autores perenes da litera-

2. Não há informações completas sobre a entrevista, embora muitos e diversos sites a reproduzam. É possível acessá-la neste link: http://www.youtube.com/watch?v=5yeFhO4G2oq. 
tura brasileira. Mesmo em termos de sua recepção crítica, há muito cresce a produção acadêmica dedicada a sua obra. Que dizer, então, dos poemas musicados por Zeca Baleiro, artista nada impopular? Ou de eventos e publicações que lhe são frequentemente dedicados?

Essa hipótese, porém, é frágil se amparada apenas na antologia. Concentrada essencialmente nas décadas de 1980 e 1990, a seleção retrata com nitidez uma autora que soube escrever entrevistas. Mas só com o conhecimento mais amplo do início e do fim da carreira é possível testemunhar como Hilst, consciente do difícil destino da literatura não comercial, desde o início se empenhou na composição de uma "cara" que julgasse adequada ao público em geral - esforço de que participam as constantes reelaborações de estratégias.

Nenhuma antologia, porém, nasce com o destino de contradizer sua vocação e tornar-se totalizante. A edição tem o mérito de propor um perfil consistente e saboroso de Hilda Hilst - proposta visível inclusive no luxuoso projeto gráfico, concebido a partir de desenhos da própria autora. Que a frase do título sirva, então, de leitmotiv para a narrativa esboçada pela seleção de entrevistas. "Fico besta de ver como as pessoas não entendem o que escrevi", afirma a personagem; e completa: "Recuso-me a dar explicações". Com a palavra, Hilda Hilst, autora de Hilda Hilst.

Luisa Destri, doutoranda em Literatura Brasileira na usp, organizou a antologia Uma superfície de gelo ancorada no riso (Globo, 2012), de Hilda Hilst, e é coautora de Por que ler Hilda Hilst (Globo, 2010). 